\title{
ANALISIS FAKTOR SOSIAL EKONOMI YANG MEMPENGARUHI PENDAPATAN PETANI BUNGA POTONG KRISAN DI KECAMATAN BANDUNGAN, KABUPATEN SEMARANG
}

\author{
Yiswi Indah Kusumaningtyas ${ }^{1)}$, Mohamad Harisudin²), Umi Barokah' \\ Fakultas Pertanian, Jurusan Agribisnis, Universitas Sebelas Maret, Jl. Ir. Sutami No. 36A Kentingan \\ Surakarta 5712, Telp (0271) 637457, email:yiswiindah10@gmail.com
}

\begin{abstract}
Abstrak
Penelitian ini bertujuan untuk mengetahui besar biaya dan pendapatan petani, mengetahui faktor sosial ekonomi apa saja yang mempengaruhi pendapatan petani dan mengetahui faktor sosial ekonomi apa yang paling mempengaruhi pendapatan petani pada usahatani bunga potong krisan di Kecamatan Bandungan, Kabupaten Semarang. Metode dasar dalam penelitian ini adalah metode eksplanatori. Pemilihan lokasi penelitian dilakukan dengan metode purposive sampling, lokasi penelitian di Kecamatan Bandungan yaitu di Desa Duren, Desa Jetis, Desa Kenteng, Desa Candi, Desa Banyukuning dan Kelurahan Bandungan sebagai desa/kelurahan yang membudidayakan bunga potong krisan. Pengambilan sampel menggunakan teknik accidental sampling sebanyak 71 orang. Metode analisis data yang digunakan meliputi analisis usahatani dan analisis faktor sosial ekonomi. Hasil penelitian ini menunjukkan: Rata-rata besarnya biaya usahatani bunga potong krisan Rp. 12.845.398/MT dan rata-rata besarnya pendapatan usahatani bunga potong krisan adalah sebesar Rp. 21.824.609/MT. Faktor-faktor jumlah tenaga kerja luar, luas lahan yang diusahakan, pengalaman usahatani, dan keikutsertaan petani dalam pengelolaan agrowisata berpengaruh terhadap pendapatan petani dalam usahatani bunga potong krisan di Kecamatan Bandungan, Kabupaten Semarang, sedangkan yang paling berpengaruh adalah luas lahan yang diusahakan.
\end{abstract}

Kata kunci: Bunga Potong Krisan, Regresi, Sosial ekonomi, Usahatani

\begin{abstract}
The study aims to determine the cost and income of farmers, knowing the socio-economic factors that influence the income and knowing the socio-economic factors that most influence the income of chrysanthemum cut flower farmers in BandunganDistrict, Semarang Regency. The basic method of greeting this research is explanatory method. The location of the study was conducted by purposive sampling method, the research locations in BandunganDistrict are in Duren Village, Jetis Village, Kenteng Village, Candi Village, Banyukuning Village and BandunganUrban Village as villages that cultivate chrysanthemum cut flowers. Sampling uses accidental sampling technique consisting 71 poeple. Data analysis methods used include farming analysis and analysis of socio-economic factors. The results of this study indicate: The average cost of farming chrysanthemum cut flowers during one period is IDR. 12.845.398 and the average income of chrysanthemum cut flower farming during one period is IDR. 21.824.609. Factors of the amount of outside labor, cultivated land area, farming experience, and farmer participation in agrotourism management influence the income of farmers in chrysanthemum cut flower farming in Bandungan District, Semarang Regency, and the most influence is cultivated land area.
\end{abstract}

Keywords: Chrysanthemum Cut Flowers, Regression, Socio-economic, Farming. 


\section{PENDAHULUAN}

Komoditas hortikultura di Indonesia merupakan komoditas yang mempunyai nilai ekonomi tinggi salah satunya bunga potong. Produksi bunga potong mengalami peningkatan yang paling tinggi jika dibandingkan dengan komoditas hortikultura yang lain. Hal ini mengindikasikan bahwa terdapat kenaikan permintaan terhadap bunga potong sehinga petani meningkatkan produksinya untuk memenuhi permintaan (Dirjen Hortikultura, 2015). Bunga potong yang memiliki nilai ekonomis tinggi adalah krisan, mawar, sedap malam,anggek, garbera, gladiol, anyelir, anthurium, dan helocinia yang diproduksi di berbagai wilayah di Indonesia salah satunya Jawa Tengah. Produksi tertinggi bunga potong di Jawa Tengah adalah bunga potong krisan (BPS Jawa Tengah, 2017).Krisan saat ini menjadi bunga potong trensetter dan populer di kalangan masyarakat karena keindahan bentuk serta keragaman warnanya (Purwanto dan Tri, 2009). Konsumen yang banyak mencari bunga potong krisan adalah pengusaha restoran, kantor, dan konsumen individu yang menggunakan bunga potong krisan sendiri (Herdiani, 2014).

Banyaknya peminat bunga potong krisan mengakibatkan banyak pula daerah yang memproduksi bunga potong krisan di Jawa Tengah. Kabupaten Semarang merupakan daerah penghasil bunga potong krisan terbanyak pada tahun 2016 jika dibandingkan dengan Kabupaten Wonosobo, Kabupaten Temanggung, Kabupaten Karanganyar, Kabupaten Batang, dan Kabupaten Wonogiri (BPS Jawa Tengah, 2017). Hal ini menunjukkan bahwa bunga potong krisan diminati petani untuk dikembangkan di Kabupaten Semarang. Produksi dan produktivitas bunga potong krisan di Kabupaten Semarang mengalami fluktuasi dari tahun 2011 sampai tahun 2016 (BPS Kabupaten Semarang, 2017. Adanya fluktuasi ini disebabkan oleh berbagai macam faktor yang tentunya akan mempengaruhi pendapatan petani bunga potong krisan di Kabupaten Semarang termasuk di Kecamatan Bandungan yang merupakan sentra bunga potong krisan. Berdasarkan kondisi di lapang, luas penggunaan lahan pada usahatani bunga potong krisan antar petani bervariasi. Berbagai jenis varietas bunga potong krisan dibudidayakan oleh pertani dengan kualitas yang berbeda-beda yang akan menentukan harga jual bunga potong krisan. Kecamatan Bandungan sendiri memiliki potensi agrowisata yang menjadikan petani mengelola usahataninya sebagai lokasi agrowisata sebelum bunga potong krisan di panen, tetapi tidak semua petani mampu memanfaatkan prospek agrowisata tersebut. Berdasarkan keadaan tersebut perlu adanya analisis lebih lanjut terkait faktor-faktor sosial ekonomi yang mempengaruhi pendapatan patani bunga potong krisan di Kecamatan Bandungan, Kabupaten Semarang.

\section{METODE}

Penelitian ini dilaksanakan di Kecamatan Bandungan di Desa Duren, Desa Jetis, Desa Kenteng, Desa Candi, Desa Banyukuning dan Kelurahan Bandungan secara purposif dengan pertimbangan menurut UPTP Hortikultura Kecamatan Bandungan (2016) hanya desa dan kelurahan tersebut yang melakukan usahatani bunga potong krisan (Singarimbun dan Effendi, 1995). Jumlah sampel dalam penelitian ini dihitungmenggunakan formula slovinmengacupada Suhartanto (2014). Berikut adalah rumus dari Formula Slovin:

$n=\frac{N}{1+\mathrm{N} e^{2}}$

Keterangan:

$$
\begin{array}{ll}
\mathrm{n} & : \text { Jumlah sampel } \\
\mathrm{N} & : \text { Populasi } \\
\mathrm{E} & : \text { Margin error }(10 \%)
\end{array}
$$

Diperoleh 71 sampel yang tersebar di lima desa dan satu kelurahan. Jumlah sampel tiap desa dihitung menggunakan metode proportional random sampling. Teknik sampling pada penelitian ini menggunakan teknik accidental sampling (Umar, 2003). Metode analisis data yang digunakan untuk menjawab tujuan dari penelitian ini adalah sebagai berikut:

Tujuan 1 : Mengetahui besar biaya dan pendapatan petani pada usahatani bunga potong krisan di Kecamatan Bandungan, Kabupaten Semarang.

Analisis biaya dilakukan dengan konsep biaya alat-alat luar. Menurut Suratiyah (2015), biaya alat-alat luar merupakan semua yang digunakan untuk menghasilkan pendapatan kotor kecuali upah tenaga kerja keluarga, bunga seluruh aktiva yang dipergunakan dan biaya untuk kegiatan petani 
itu sendiri, secara sistematis dapat dituliskan sebagai berikut:

Biaya alat-alat luar = biaya saprodi + biaya tenaga kerja luar + biaya lainnya.

Penerimaan usahatani bunga potong krisan adalah perkalian antara produksi dan harga bunga potong krisan. Pernyataan tersebut dapat dirumuskan sebagai berikut:

Total penerimaan $=\mathrm{Y}$. Py

Keterangan:

$\mathrm{Y}$ : Produksi bunga potong krisan (ikat)

Py: harga buga potong krisan (Rp/ikat)

Pendapatan usahatani adalah selisih

dari total penerimaan dan biaya total. Besarnya pendapatan petani bunga potong krisan di Kecamatan Bandungan, Kabupaten Semarang dapat dinotasikan dengan rumus:

Pendapatan $=$ Total penerimaan - Biaya alat alat luar

Tujuan 2: mengetahui faktor sosial ekonomi apa saja yang mempengaruhi pendapatan petani dan mengetahui faktor apa yang paling berpengaruh pada usahatani bunga potong krisan di Kecamatan Bandungan, Kabupaten Semarang.

Analisis yang digunakan untuk mengetahui faktor-faktor yang mempengaruhi pendapatan usahatani bunga potong krisan adalah analisis regresi linier berganda. Menurut Gujarati (2006) persamaannya sebagai berikut:

$Y=a+b_{1} X_{1}+b_{2} X_{2}+b_{3} X_{3}+b_{4} X_{4}+b_{5} X_{5}+b_{6} X_{6}+b_{7} X_{7}+b_{8} D_{1}$ $+e$

Keterangan:

Y : Pendapatan Petani Bunga Potong Krisan (Rp)

a : Bilangan Konstanta

b : Koefisien Regresi

e : error

$\mathrm{X}_{1}$ : Jumlah tenaga kerja luar (HKP)

$\mathrm{X}_{2}$ : Luas lahan yang diusahakan (ha)

$X_{3}$ : Harga jual (Rp/lkat)

$\mathrm{X}_{4}$ : Pendidikan petani (Th)

$\mathrm{X}_{5}$ : Pengalaman usahatani (Th)

$\mathrm{X}_{6}$ : Usia petani $(\mathrm{Th})$
$\mathrm{X}_{7}$ : Jumlah tanggungan keluarga (orang)

$\mathrm{D}_{1}$ : Keikutsertaan petani dalam pengelolaan agrowisata

$\mathrm{d}_{1}=1$ : anggota agrowisata

$\mathrm{d}_{1}=0$ : non-anggota agrowisata

Analisis yang digunakan untuk mengetahui faktor yang paling mempengaruhi pendapatan usahatani bunga potong krisan adalah analisis regresi linier berganda dilihat pada tabel coefficien, dengan melihat nilai $t$ hitung yang paling besar.

\section{HASIL DAN PEMBAHASAN}

\subsection{Karakteristik Responden}

Tabel 1 menunjukkan bahwa petani bunga potong krisan berada pada usia produktif yang artinya petani bunga potong krisan dapat mengerjakan kegiatan dalam usahatani secara optimal dengan mencurahkan tenaga fisik yang tersedia (Mantra, 2004). Selain itu petani bunga potong krisan masih mempunyai kemampuan bekerja yang tinggi untuk mengelola dan melakukan budidaya bunga potong krisan. Anggota keluarga merupakan sumber tenaga kerja dalam usahatani bunga potong krisan. Semakinbanyak anggota keluarga yang aktif dalam kegiatan usahatni, berpeluang memperoleh pendapatan lebih tinggi karena dapat menghemat biaya (Asih, 2009).

Tingkat pendidikan petani bunga potong krisan tergolong rendah karena hanya $25,4 \%$ petani yang sudah menempuh pendidikan hingga jenjang SMA. Hal ini akan mempengaruhi cara pandang dan berpikir petani dalam mengambil keputusan yang berhubungan dengan usahaani bunga potong krisan seperti pengeluaran biaya dan pendapatan (Hernanto, 1984). Mayoritas pengalaman petani bunga potong krisan sudah lebih dari 10 tahun yang berarti petani dapat meningkatkan kemampuan petani dalam membudidayakan bunga potong krisan. Petani akan semakin paham mengenai karakteristik bunga potong krisan serta kendala yang dihadapi dalam budidaya bunga potong krisan. Mayoritas petani anggota agrowisata melakukan usahatani bunga potong krisan pada lahan seluas $0,100-0,119$ ha, hal ini karena petani tersebut merupakan petani senior yang sudah lama melakukan 
usahatani bunga potong krisan sehingga lahan yang diusahakan juga luas.

\subsection{Analisis Biaya Usahatani Bunga Potong Krisan di Kecamatan Bandungan, Kabupaten Semarang}

Total biaya produksi yang dikeluarkan petani dalam usahatani bunga potong krisan di Kecamatan Bandungan, Kabupaten Semarang merupakan biaya alat-alat luar yang besarnya mempengaruhi pendapatan petani bunga potong krisan.Berdasarkan Tabel 2, dapat diketahui bahwa biaya alat-alat luar paling besar pada usahatani bunga potong krisan di Kecamatan Bandungan, Kabupaten Semarang adalah biaya sarana produksi. Hal ini karenakan pentingnya sarana produksi untuk berlangsungnya usahatani bunga potong krisan. Rata-rata biaya terbesar yang dikeluarkan petani bunga potong krisan adalah untuk pemenuhan sarana produksi yang terdiri dari bibit, pupuk dan pestisida yang menjadi faktor pokok dalam suatu usahatani. Petani bersedia mengeluarkan biaya sarana produksi meskipun dengan nominal yang besar. Rata-rata biaya yang dikeluarkan untuk tenaga kerja pada usahatani bunga potong krisan sebesar Rp. 517.678 yang tergolong kecil karena pada usahatani bunga potong krisan walaupun terdapat banyak kegiatan yang dilakukan oleh petani tetapi biaya yang dikeluarkan oleh petani hanya untuk tenaga kerja luar saja. Tenaga kerja dalam keluarga pada usahatani keluarga tidak diberikan upah, padahal dalam kenyataanya tenaga kerja yang banyak digunakan dalam usahtani bunga potong krisan di Kecamatan Bandungan, Kabupaten Semarang adalah tenaga kerja keluarga. Sehingga biaya tenaga kerja akan menjadi besar apabila petani juga mengeluarkan biaya untuk upah tenaga kerja dalam keluarga. Rata-rata biaya yang dikeluarkan petani bunga potong krisan dalam satu kali masa tanam adalah Rp. 12.845.398.

\subsection{Analisis Penerimaan Usahatani Bunga Potong Krisan di Kecamatan Bandungan, Kabupaten Semarang}

Penerimaan merupakan hasil kali jumlah produksi dengan harga jual. Penerimaan usahatani bunga potong krisan di Kecamatan Bandungan, Kabupaten Semarang memiliki varian harga yang berbeda-beda.Berdasarkan Tabel 3, dapat dijelaskan bahwa petani bunga potong krisan di Kecamatan Bandungan, Kabupaten Semarang membudidayakan bunga potong krisan dengan jenis sheena, bacardi, puspita nusantara, dewi ratih, remix, fiji dan lamet dengan adanya benggolongan grade (kualitas). Bunga potong krisan dapat dikelompokkan dalam grade $\mathrm{A}$ apabila panjang batang lebih dari $80 \mathrm{~cm}$, batang bunga besar dan kuat, tingkat kemekaran bunga $70 \%-80 \%$ saat panen, dan satu ikat bunga terdapat 10 tangkai. Kriteria bunga potong krisan yang masuk grade $\mathrm{B}$ adalah terdapat 1 atau 2 bunga yang pecah warna (warna tidak merata) dan mekar penuh saat dipanen, bunga kecil, tangkai tanaman lemah, panjang tangkai kurang dari $80 \mathrm{~cm}$ dan satu ikat bunga terdapat 12-15 tangkai bunga. Penggolongan grade akan memberikan perbedaan pada harga masing-masing grade. Bunga potong krisan dengan grade $\mathrm{A}$ dapat dijual dengan harga diatas Rp. 15.000, sedangkan untuk grade $B$ dapat dijual dengan harga setengah dari grade $A$.

Pada Tabel 3 menunjukkan tiga penerimaan terbanyak adalah jenis sheena, bacardi, dan puspita nusantara. Mayoritas petani bunga potong krisan memproduksi tiga jenis bunga tersebut karena ketiga jenis bunga tersebut selalu dicari oleh pembeli sehingga petani berusaha selalu menyediakan bunga potong krisan jenis shenna, bacardi dan puspita nusantara. Sedangkan jenis bunga yang paling sedikit diproduksi adalah jenis fiji. Hal ini karena bunga potong krisan jenis fiji termasuk dalam bunga potong krisan jenis standar yang hanya memiliki satu kuntum dalam satu batang. Sehingga risiko kerugian lebih besar apabila terjadi kerusakan. Selain itu, konsumen lebih menyukai bunga potong krisan tipe spray daripada tipe standar karena dalam 1 tangkai terdapat banyak bunga yang mekar, warna 
bunga lebih bervariasi dan harga lebih murah karena dalam satu tangkai terdapat banyak kuntum bunga.

\subsection{Analisis Pendapatan Usahatani Bunga Potong Krisan di Kecamatan Bandungan, Kabupaten Semarang}

Pendapatan merupakan hasil dari selisih penerimaan dengan biaya total. Penerimaan merupakan hasil kali produksi total bunga potong krisan. Sedangkan biaya total yang digunakan dalam penelitian ini adalah biaya alat alat luar yang terdiri dari biaya sarana produksi,biaya tenaga kerja luar dan biaya lain-lain.

Berdasarkan Tabel 4, diketahui bahwa pendapatan petani bunga potong krisan di Kecamatan Bandungan, Kabupaten Semarang sebesar Rp. 21.824.609 per masa tanam (4 bulan) dengan biaya alat-alat luar sebesar Rp. 12.845.398 per masa tanam. Produksi bunga potong krisan di Kecamatan Bandungan menunjukkan hasil positif, hal ini dikarenakan petani melakukan perawatan secara intensif sehingga usahatani bunga potong krisan menjadi subur, kebutuhan air tercukupi, kerusakan akibat OPT dapat dikendalikan dan tanaman mendapatkan unsur hara yang sesuai dengan kebutuhan tanaman. Namun, dalam perawatan yang intensif dan baik tentu rata-rata biaya total menjadi besar, hal ini disebabkan petani petani mengeluarkan biaya untuk membeli pupuk serta pestisida agar pertumbuhan bunga potong krisan dapat subur sehingga kuntum bunga yang dihasilkan juga bagus. Selain itu, biaya untuk kebutuhan listrik bunga potong krisan juga sangat diperlukan, apabila penyinaran pada bunga potong krisan tidak sesuai atau kurang maka tanaman akan layu dan bunga tidak dapat tumbuh dengan sempurna.

Jumlah pendapatan usahatani dari hasil penjualan bunga potong krisan yang diperoleh petani anggota agrowisata maupun petani non- anggota agrowisata hanya memiliki selisih sedikit. Namun, petani anggota agrowisata akan memperoleh tambahan pendapatan selain dari penjualan hasil panen bunga potong krisan, yaitu dari penjualan tiket masuk agrowisata. Rata-rata pendapatan yang diperoleh petani yang ikutserta dalam agrowisata sebesar Rp. 2.695.100.

\subsection{Analisis Faktor Sosial Ekonomi yang Mempengaruhi Pendapatan Petani pada Usahatani Bunga Potong Krisan di Kecamatan Bandungan, Kabupaten Semarang}

Hubungan antar faktor sosial ekonomi petani bunga potong krisan terhadap pendapatan petani bunga potong krisan di Kecamatan Bandungan, Kabupaten Semarang ditunjukkan dengan fungsi model regresi linier berganda (Ghozali, 2005). Faktor sosial ekonomi yang dimasukkan ke dalam persamaan adalah jumlah tenaga kerja luar, luas lahan yang diusahakan, harga jual, pendidikan 82 man usahatani, usia petani æn petani dalam pengelolaan agrowisata. Adapun model fungsi regresi linier berganda faktor sosial ekonomi adalah sebagai berikut:

$\mathrm{Y}=1180711,810-47322,503 \mathrm{X}_{1}+2,636 \mathrm{E} 8 \mathrm{X}_{2}$ $+112,016 X_{3}-215886,102 X_{4}-188233,037 X_{5}+$ $1142,241 X_{6}-233923,499 X_{7}+2003576,871 D_{1}$

Keterangan:

$\mathrm{Y}$ : Pendapatan petani bunga potong krisan (Rp)

$\mathrm{X}_{1}$ : Jumlah tenaga kerja luar (HKP)

$\mathrm{X}_{2}$ : Luas lahan yang diusahakan (ha)

$\mathrm{X}_{3}$ : Harga jual (Rp/lkat)

$\mathrm{X}_{4}$ : Pendidikan petani (Th)

$\mathrm{X}_{5}$ : Pengalaman usahatani (Th)

$\mathrm{X}_{6}$ : Usia petani (Th)

$\mathrm{X}_{7}$ : Jumlah tanggungan keluarga (orang)

$D_{1}$ : Keikutsertaan petani dalam pengelolaan agrowisata

\subsubsection{Uji Koefisien Determinasi $\left(\mathbf{R}^{2}\right)$}

Analisis determinasi digunakan untuk mengetahui seberapa jauh variabel 
mempengaruhi dapat menjelaskan variabel dipengaruhi. Besarnya pengaruh faktor-faktor sosial ekonomi terhadap pendapatan petani bunga potong krisan di Kecamatan Bandungan, Kabupaten Semarang ditunjukkan oleh koefisien determinasi $R$ Square dan dinyatakan dalam satuan persen. Hasil analisis determinasi dapat dilihat pada output Model Summary (Priyatno, 2009).

Berdasarkan Tabel 5, diperoleh nilai $R$ Square sebesar 0,951. Sehingga berdasarkan nilai $\mathrm{R}$ Square yang telah diketahui maka variasi variabel-variabel bebas yang meliputi jumlah tenaga kerja luar, luas lahan yang diusahakan, harga jual, pendidikan petani, pengalaman usahatani, usia petani, jumlah tangggungan keluarga, dan keikutsertaan petani dalam pengelolaan agrowisata yang digunakan dalam model mampu menjelaskan sebesar $95,1 \%$ variasi variabel terikat (pendapatan petani). Sedangkan sisanya sebesar $4,9 \%$ dipengaruhi oleh variabel lain yang tidak dimasukkan ke dalam model seperti permintaan pasar, iklim, dan cuaca.

\subsubsection{Hasil Uji F (Over-all test)}

Uji F digunakan untuk menguji apakah variabel bebas secara bersama-sama berpengaruhi terhadap variabel terikat. Penelitian ini dilakukan uji $F$ untuk mengetahui apakah jumlah tenaga kerja luar, luas lahan yang diusahakan, harga jual, pendidikan petani, pengalaman usahatani, usia petani, dan keikutsertaan petani dalam pengelolaan agrowisata secara bersama-sama berpengaruh terhadap pendapatan petani bunga potong krisan di Kecamatan Bandungan, Kabupaten Semarang. Hasil uji F dapat dilihat pada output Anova.

Berdasarkan Tabel 6, diketahui bahwa nilai $F$ hitung sebesar 148,976 dan nilai $F_{0,05 ; 8 ; 62}$ adalah 2,09. Sehingga nilai $F$ hitung $>$ nilai $F$ tabel. Hal ini menunjukkan bahwa variabel-variabel bebas yang digunakan dalam penelitian yang meliputi jumlah tenaga kerja luar, luas lahan yang diusahakan, harga jual, pendidikan petani, pengalaman usahatani, usia petani, dan keikutsertaan petani dalam pengelolaan agrowisata secara bersama-sama berpengaruh nyata terhadap variabel terikat yaitu pendapatan petani bunga potong krisan di Kecamatan Bandungan, Kabupaten Semarang. Hal ini seperti yang diungkapkan oleh Suratiyah (2015), bahwa terdapat dua faktor yang mempengaruhi biaya dan pendapatan yaitu faktor internal dan faktor eksternal. Kedua faktor tersebut akan bersama-sama mempengaruhi biaya dan pendapatan.

\subsubsection{Hasil Uji $t$}

Uji statistik t digunakan untuk mengetahui seberapa jauh pengaruh variabel bebas jumlah tenaga kerja luar, luas lahan yang diusahakan, harga jual, pendidikan petani, pengalaman usahatani, usia petani, dan keikutsertaan petani dalam pengelolaan agrowisata secara individu dapat menerangkan variasi variabel pendapatan petani bunga potong krisan di Kecamatan Bandungan, Kabupaten Semarang. Hasil uji $t$ dapat dilihat pada output tabel cefficient (Priyatno, 2009).

Berdasarkan hasil nilai $\mathrm{t}$ tabel yang diperoleh dengan nilai $\mathrm{df}=62$ adalah $\mathrm{t}_{0,05: 62}=$ 1,999. Tabel 7 menunjukkan bahwa nilai $t$ hitung jumlah tenaga kerja luar bernilai negatif sebesar 2,412. Nilai t hitung jumlah tenaga kerja luar $>\mathrm{t}$ tabel secara individu jumlah tenaga kerja luar (X1) berpengaruh nyata terhadap pendapatan petani bunga potong krisan (Y). Nilai koefisien regresi biaya tenaga kerja bernilai negatif, berarti kenaikan satu satuan jumlah tenaga kerja luar dapat menurunkan pendapatan petani bunga potong krisan sebesar Rp. 47.322,503. Menurut Suratiyah (2015), banyak sedikitnya tenaga kerja yang diperlukan dalam usahatani tergantung dari jenis tanaman yang diusahakan. Penambahan tenaga kerja dari luar keluarga akan menambah pula biaya yang dikeluarkan petani sehingga biaya yang dikeluarkan oleh petani untuk tenaga kerja akan semakin meningkat sehingga dapat mengurangi pendapatan petani. Selaras dengan penelitian Rangkuti et. al. (2014). 
Agrisaintifika

Jurnal Ilmu-Ilmu Pertanian

Vol 3, No. 1, 2019

Kusumaningtyas, et al. 2019

Nilai t hitung luas lahan yang diusahakan bernilai positif sebesar 30,107 . Nilai t hitung luas lahan yang diusahakan $>t$ tabel sehingga secara individu luas lahan yang diusahakan (X2) berpengaruh nyata terhadap pendapatan petani bunga potong krisan $(\mathrm{Y})$. Nilai koefisien regresi luas lahan yang diusahakan bernilai positif, berarti kenaikan satu satuan luas lahan yang diusahakan dapat menaikkan pendapatan petani bunga potong krisan sebesar Rp. 263.600.000. Kondisi lahan di Kecamatan Bandungan, Kabupaten Semarang cocok untuk dijadikan lahan pertanian karena memiliki terdapat di lereng Gunung Ungaran yang mendukung perkembangan pertanian di wilayah Kecamatan Bandungan.Menurut Suratiyah (2015), semakin luas lahan yang digunakan maka semakin tinggi produksi dan pendapatan per satuan luas. Luaslahan yang diusahakan merupakan variabel bebas yang paling berpengaruh terhadap pendapatan petani bunga potong krisan karena nilai $t$ hitung paling besar dibandingan dengan variabel bebas yang lain. Selaras dengan penelitian Rangkuti et. al. (2014), Assis et. al. (2014) dan Serin et. al (2009)

Nilai $t$ hitung harga jual bernilai positif sebesar 0,280 . Nilai $t$ hitung harga jual $<t$ tabel secara individu harga jual (X3) tidak berpengaruh nyata terhadap pendapatan petani bunga potong krisan $(Y)$. Nilai koefisien regresi harga jual bernilai negatif sebesar 112,016. Menurut Suratiyah (2015), jika permintaan akan produksi tinggi maka harga di tingkat petani tinggi pula sehingga dengan biaya yang sama petani akan memeperoleh pendapatan yang tinggi pula. Namun, di lokasi penelitian harga jual bunga potong krisan tidak berpengaruh nyata terhadap pendapatan petani karena pada kenyataannya biaya yang dikeluarkan oleh petani tidak sama.

Nilai $t$ hitung pendidikan petani bernilai negatif sebesar 1,642. Nilai $t$ hitung pendidikan petani $<t$ tabel secara individu pendidikan (X4) tidak berpengaruh nyata terhadap pendapatan petani bunga potong krisan (Y). Nilai koefisien regresi pendidikan bernilai negatif sebesar 215.886,102. Pendidikan petani tidak berpengaruh nyata terhadap pendapatan petani bunga potong krisan karena pendidikan yang dimaksud dalam peneltian ini adalah pendidikan formal. Selain itu, sebagian besar petani memiliki tingkat pendidikan formal yang rendah. Seperti yang diungkapkan oleh Suratiyah (2015), bahwapendidikan terutama pendidikan nonformal seperti kursus kelompok tani, penyuluhan, dan studi banding akan menambah pengetahuan petani, menambah ketrampulan dan pengalaman petani dalam mengelola usahatani. Selaras dengan penelitian Assis et. al. (2014).

Nilai $t$ hitung pengalaman usahatani bernilai positif sebesar 2,655. Nilai $t$ hitung pengalaman usahatani $>t$ tabel sehingga secara individu pengalaman usahatani (X5) berpengaruh nyata terhadap pendapatan petani bunga potong krisan $(Y)$. Nilai koefisien regresi pengamalan usahatani bernilai positif berarti kenaikan satu satuan pengalaman dapat meningkatkan pendapatan petani bunga potong krisan sebesar Rp. 188.233,037. Petani yang memiliki pengalaman lebih lama dapat menentukan keputusan apa yang tepat sesuai dengan pengalaman petani di masa sebelumnya. Menurut Rangkuti et al. (2014), belajar dengan mengamati pengalaman petani lain juga sangat penting karena merupakan cara yang lebih baik untuk mengambil keputusan daripada dengan cara mengolah sendiri informasi yang ada.

Nilai $\mathrm{t}$ hitung usia petani bernilai positif sebesar 0,039 . Nilai $t$ hitung usia petani $<t$ tabel secara individu usia petani (X6) tidak berpengaruh nyata terhadap pendapatan petani bunga potong krisan $(Y)$. Nilai koefisien regresi usia petani bernilai positif sebesar 1.142,241. Usia petani tidak berpenggaruh nyata terhadap pendapatan petani bunga potong krisan karena tingkat usia petani bunga potong krisan di Kecamatan Bandungan, Kabupaten Semarangtidak sama 
Agrisaintifika

Jurnal Ilmu-Ilmu Pertanian

Vol 3, No. 1, 2019

Kusumaningtyas, et al. 2019

yaitu terdapat petani muda dan petani tua. Menurut Suratiyah (2015), Semakin tua usia maka secara fisik akan terasa berat pekerjaannya, sehingga akan semakin turun prestasinya. Selain itu, dalam hal tanggung jawab semakin tua usia maka akan semakin berpengalaman. Namun, petani bunga potong krisan di Kecamatan Bandungan, Kabupaten Semarang yang masih berusia muda juga mempunyai pengalaman yang sama dengan petani yang memiliki usia tua. Selaras dengan penelitian Assis et. al. (2014).

Nilai t hitung jumlah tanggungan keluarga bernilai negatif sebesar 0,922 . Nilai $t$ hitung jumlah tanggungan keluarga $<\mathrm{t}$ tabel sehingga individu tanggungan keluarga (X7) tidak berpengaruh nyata terhadap pendapatan petani bunga potong krisan $(\mathrm{Y})$. Nilai koefisien regresi jumlah tanggungann keluarga petani bernilai negatif sebesar 233.923,499. Menurut Asih (2009), semakin banyak anggota keluarga yang aktif dalam kegiatan usahatani, berpeluang memperoleh pendapatan yang lebih tinggi daripada petani lain dengan jumlah anggota keluarga yang tidak aktif. Pada penelitian ini jumlah tanggungan keluarga secara individu tidak berpengaruh nyata terhadap pendapatan petani bunga potong krisan. Hal ini karena, tanggungan keluarga yang terlibat dalam budidaya bunga potong krisan adalah istri dari petani, anak-anak petani tidak ikut aktif dalam usahatani karena dianggap belum mampu melakukan pekerjaan dalam budiaya bunga potong krisan tersebut. Penelitian ini didukung dengan penelitian yang dilakukanoleh Filardi dan Septina (2014), menyatakan bahwa hubungan jumlah tanggungan keluarga dengan pendapatan tidak signifikan.

Nilai t hitung keikutsertaan petani dalam pegelolaan agrowisata bernilai positif sebesar 3,219 . Nilai $t$ hitung keikutsertaan petani dalam pegelolaan agrowisata $>\mathrm{t}$ tabel sehingga secara individu Keikutsertaan petani dalam pegelolaan agrowisata (D) berpengaruh nyata terhadap pendapatan petani bunga potong krisan $(\mathrm{Y})$. Nilai koefisien regresi keikutsertaan petani dalam pegelolaan agrowisata bernilai positif sebesar sehingga keikutsertaan petani dalam agrowisata menambah pendapatan petani bunga potong krisan sebesar Rp. 2.003.576, 871. Pada lokasi penelitian hanya terdapat 2 desa yang mempunyai agrowisata bunga potong krisan, yaitu Desa Jetis (Setya Aji Flower Farm) dan Desa Duren (Kampung Krisan Clapar). Pembagian hasil pemasukan dari penjualan tiket adalah sebanyak $30 \%$ untuk petani. Petani bunga potong krisan yang lahannya digunakan sebagi lokasi agrowisata bunga potong krisan akan memperoleh tambahan pendapatan tanpa harus mengeluarkan biaya.

\section{KESIMPULAN}

Berdasarkan hasil penelitian mengenai Faktor-Faktor Sosial Ekonomi yang Mempengaruhi Pendapatan Petani Bunga Potong Krisan di Kecamatan Bandungan, Kabupaten Semarang dapat ditarik kesimpulan sebagai berikut (1) Rata-rata besarnya biaya usahatani bunga potong krisan di Kecamatan Bandungan, Kabupaten Semarang selama satu kali musim tanam adalah sebesar Rp. 12.845 .398 dan rata-rata besarnya pendapatan usahatani bunga potong krisan di Kecamatan Bandungan, Kabupaten Semarang selama satu kali musim tanam yang diperoleh adalah sebesar Rp. 21.824.609. (2) Faktor sosial ekonomi jumlah tenaga kerja luar, luas lahan yang diusahakan, pengalaman usahatani, dan keikutsertaan petani dalam pengelolaan agrowisata berpengaruh terhadap pendapatan petani dalam usahatani bunga potong krisan di Kecamatan Bandungan, Kabupaten Semarang. Hanya faktor kebutuhan tenaga kerja luar yang berpengaru negatif, sedangkan faktor luas lahan yang diusahakan, pengalaman usahatani dan keikutsertaan petani dalam pengelolaan agriwisata berpengaruh positif. Faktor sosial ekonomi yang paling berpengaruh terhadap pendapatan petani dalam usahatani bunga potong krisan di Kecamatan Bandungan, 
Kusumaningtyas, et al. 2019

Kabupaten Semarang adalah luas lahan yang diusakan oleh petani bunga potong krisan.

\section{DAFTAR PUSTAKA}

Asih, D. N. 2009. Analisis Karakteristik dan Tingkat Pendapatan Usahatani Bawang Merah di Sulawesi Tengah. Jurnal Agroland 1(16): 53-59.

Assis, N. A. dan Mohammad A. 2014. Relationship Between Socioeconomic Factors, Income, and Productivity of Farmers: A Case Study on Pineapple Farmers. International Journal of Research in Humanities, Arts adn Literature 2(12): 67-78.

BPS Jawa Tengah 2017. Jawa Tengah dalam Angka. Jawa Tengah: BPS.

BPS Kabupaten Semarang. 2017. Kabupaten Semarang dalam Angka. Kabupaten Semarang: BPS.

Dirjen Hortikultura. 2015. Statistik Produksi Hortikultura Tahun 2014. Jakarta: Direktoran Jendral Hortikultura Kementrian Pertanian.

Filardi dan Septina. 2014. Faktor-Faktor Sosial Ekonomi yang Mempengaruhi Pendapatan Usahatani Padi Sawah Petani Kooperator di Desa Sungai Geringging Kecamatan Kampar Kiri Kabupaten Kampar. Riau : Universitas Islam Riau.

Ghozali, I. 2005. Aplikasi Analisis Multivariate dengan Program SPSS. Semarang: UNDIP.

Gujarati, D. N. 2006. Dasar-dasar Ekonometrika: Edisi Ketiga. Jakarta: Erlangga.

Herdiani, E. 2014. Pasca Panen Bunga Potong. Bandung: BBPP Lembang.

Hernanto, F. 1984. Petani Kecil Potensi dan Tantangan Pembangunan. Bandung: Gramedia.
Mantra, I.B. 2004. Demografi Umum. Yogyakarta: Penerbit Pustaka Pelajar.

Priyatno, D. 2009. SPSS untuk Analisis Korelasi, Regresi, dan Multivariate. Yogyakarta: Gava Media.

Purwanto, A. W. dan Tri Martini. 2009. Krisan, Bunga Seribu Warna. Yogyakarta: Kanisius.

Rangkuti, K, Sasmita S, Muhammad T, dan Rui A. 2014. Pengaruh Faktor Sosial Ekonomi terhadap Pendapatan Petani Jagung. Jurnal Agrium 19(1): 52-58.

Serin, Vindan, Nizamettin B, dan Abdülkadir C. 2009. Effects of Formal Education and Training on Farmers Income. European Journal of Social Sciences 7(3): 52-62.

Singarimbun, M dan Effendi. 1995. Metode Penelitian Survey. Jakarta : PT Pustaka LP3ES.

Suhartanto, D. 2014. Metode Riset Pemasaran. Bandung: Alfabeta.

Suratiyah, K. 2015. IImu Usaha Tani (Edisi Revisi). Jakarta: Penebar Swadaya.

Umar, H. 2003. Metode Riset Bisnis. Jakarta: PT. Gramedia Pustaka Utama.

UPTP Hortikultura Kecamatan Bandungan. 2016. Luas Tanaman Krisan Kecamatan Bandungan Tahun 2016. Bandungan: UPTP Hortikultura Kecamatan Bandungan. 
Agrisaintifika

Jurnal Ilmu-Ilmu Pertanian

Vol 3, No. 1, 2019

Kusumaningtyas, et al. 2019

\section{LAMPIRAN}

Tabel 1. Karakteristik Responden Petani Bunga Potong Krisan di Kecamatan Bandungan, Kabupaten Semarang

\begin{tabular}{|c|c|c|c|c|}
\hline \multirow[b]{2}{*}{$\begin{array}{l}\mathbf{N} \\
\text { o. }\end{array}$} & \multirow[b]{2}{*}{ Keterangan } & \multicolumn{2}{|c|}{ Jumlah Responden (Orang) } & \multirow[b]{2}{*}{$\begin{array}{c}\text { Presentase } \\
(\%)\end{array}$} \\
\hline & & $\begin{array}{c}\text { Anggota } \\
\text { Agrowisata }\end{array}$ & $\begin{array}{l}\text { Non-anggota } \\
\text { Agrowisata }\end{array}$ & \\
\hline \multirow[t]{4}{*}{1.} & Kelompok Usia(Th) & & & \\
\hline & $<15$ & 0 & 0 & 0,00 \\
\hline & $15-64$ & 19 & 49 & 95,80 \\
\hline & $>64$ & 1 & 2 & 4,20 \\
\hline \multirow[t]{4}{*}{2.} & $\begin{array}{l}\text { Jumlah Tanggungan } \\
\text { Keluarga(Orang) }\end{array}$ & & & \\
\hline & $<3$ & 2 & 6 & 11,27 \\
\hline & $3-6$ & 18 & 45 & 88,73 \\
\hline & $>6$ & 0 & 0 & 0,00 \\
\hline \multirow[t]{5}{*}{3.} & Kelompok Pendidikan & & & \\
\hline & Tidak Tamat SD & 0 & 3 & 4,20 \\
\hline & Tamat SD & 5 & 24 & 40,80 \\
\hline & Tamat SMP & 9 & 12 & 29,60 \\
\hline & Tamat SMA & 6 & 12 & 25,40 \\
\hline \multirow[t]{9}{*}{4.} & PengalamanResponden(Tahun) & & & \\
\hline & $1-3$ & 1 & 2 & 4,23 \\
\hline & $4-6$ & 3 & 8 & 15,49 \\
\hline & $7-9$ & 6 & 14 & 28,17 \\
\hline & $10-12$ & 4 & 15 & 26,76 \\
\hline & $13-15$ & 3 & 9 & 16,90 \\
\hline & $16-18$ & 0 & 0 & 0,00 \\
\hline & $19-21$ & 1 & 3 & 5,63 \\
\hline & $22-24$ & 2 & 0 & 2,82 \\
\hline \multirow[t]{8}{*}{5.} & Luas Lahan yang Diusahakan(ha) & & & \\
\hline & $0,020-0,039$ & 4 & 7 & 15,49 \\
\hline & $0,040-0,059$ & 4 & 10 & 19,72 \\
\hline & $0,060-0,079$ & 3 & 11 & 19,72 \\
\hline & $0,080-0,099$ & 0 & 8 & 11,27 \\
\hline & $0,100-0,119$ & 6 & 9 & 21,13 \\
\hline & $0,120-0,139$ & 0 & 2 & 2,82 \\
\hline & $0,140-0,159$ & 3 & 4 & 9,86 \\
\hline
\end{tabular}

Sumber: Analis Data Primer, 2018

Tabel 2. Rata-rata Biaya Alat-alat Luar pada Usahatani Bunga Potong Krisan di Kecamatan Bandungan, Kabupaten Semarang Periode Januari-April Tahun 2018

\begin{tabular}{|c|c|c|c|c|c|c|}
\hline \multirow[b]{2}{*}{ Uraian } & \multicolumn{2}{|c|}{ Anggota Agrowisata } & \multicolumn{2}{|c|}{ Non-anggota Agrowisata } & \multicolumn{2}{|c|}{ Seluruh Responden } \\
\hline & $\begin{array}{l}\text { Rata-rata } \\
\text { (Rp) }\end{array}$ & Persentase & $\begin{array}{l}\text { Rata-rata } \\
\text { (Rp) }\end{array}$ & Persentase & $\begin{array}{c}\text { Rata-rata } \\
(\mathbf{R p})\end{array}$ & Persentase \\
\hline $\begin{array}{l}\text { Biaya Sarana } \\
\text { Produksi }\end{array}$ & 7.254 .183 & 52,97 & 6.897 .099 & 55,13 & 6.998 .388 & 54,48 \\
\hline $\begin{array}{l}\text { Biaya Tenaga } \\
\text { Kerja Luar }\end{array}$ & 861.750 & 6,29 & 382.744 & $\overline{3,06}$ & 517.678 & 4,03 \\
\hline Biaya Lain-lain & 5.579 .171 & 40,74 & 5.230 .896 & 41,81 & 5.329 .332 & 41,49 \\
\hline Jumlah & 13.695 .104 & 100,00 & 12.510 .739 & 100,00 & 12.845 .398 & 100,00 \\
\hline
\end{tabular}

Sumber: Analisis Data Primer, 2018 
Agrisaintifika

Jurnal Ilmu-Ilmu Pertanian

Vol 3, No. 1, 2019

Kusumaningtyas, et al. 2019

Tabel 3. Rata-rata Penerimaan Petani pada Usahatani Bunga Potong Krisan di KecamatanBandungan, Kabupaten Semarang Periode Januari-April Tahun 2018

\begin{tabular}{|l|r|r|r|r|r|r|}
\hline \multirow{2}{*}{ Uraian } & \multicolumn{2}{|c|}{ Anggota Agrowisata } & \multicolumn{2}{|c|}{ Non-anggota Agrowisata } & \multicolumn{2}{|c|}{ Seluruh Responden } \\
\cline { 2 - 7 } & $\begin{array}{r}\text { Penerimaan } \\
\text { Grade A(Rp) }\end{array}$ & $\begin{array}{r}\text { Penerimaan } \\
\text { Grade B(Rp) }\end{array}$ & $\begin{array}{r}\text { Penerimaan } \\
\text { Grade A(Rp) }\end{array}$ & $\begin{array}{r}\text { Penerimaan } \\
\text { Grade B(Rp) }\end{array}$ & $\begin{array}{r}\text { Penerimaan } \\
\text { Grade A(Rp) }\end{array}$ & $\begin{array}{r}\text { Penerimaan } \\
\text { Grade B(Rp) }\end{array}$ \\
\hline Sheena & 6.000 .500 & 237.750 & 7.025 .980 & 260.049 & 6.737 .113 & 253.768 \\
\hline Bacardi & 6.871 .500 & 259.500 & 6.371 .569 & 208.039 & 6.512 .394 & 222.535 \\
\hline $\begin{array}{l}\text { Puspita } \\
\text { Nusantara }\end{array}$ & 6.607 .750 & 255.625 & 7.089 .804 & 292.167 & 6.954 .014 & 281.873 \\
\hline $\begin{array}{l}\text { Dewi } \\
\text { Ratih }\end{array}$ & 4.416 .500 & 176.750 & 3.245 .294 & 144.314 & 3.575 .211 & 153.451 \\
\hline Remix & 5.961 .250 & 227.750 & 4.742 .157 & 190.245 & 5.085 .563 & 200.810 \\
\hline Fiji & 9477.000 & 44.250 & 1.203 .529 & 33.480 & 1.131 .268 & 36.514 \\
\hline Lamet & 3.013 .000 & 122.000 & 3.536 .667 & 141.961 & 3.389 .155 & 136.338 \\
\hline Jumlah & $\mathbf{3 3 . 8 1 7 . 5 0 0}$ & $\mathbf{1 . 3 2 3 . 6 2 5}$ & $\mathbf{3 3 . 2 1 5 . 0 0 0}$ & $\mathbf{1 . 2 7 0 . 2 5 5}$ & $\mathbf{3 3 . 3 8 4 . 7 1 8}$ & $\mathbf{1 . 2 8 5 . 2 8 9}$ \\
\hline
\end{tabular}

Sumber: Analisis Data Primer, 2018

Tabel 4. Rata-rata Pendapatan Petani pada Usahatani Bunga Potong Krisan di Kecamatan Bandungan, Kabupaten Semarang Periode Januari-April Tahun 2018

\begin{tabular}{|l|r|r|r|}
\hline \multicolumn{1}{|c|}{ Uraian } & $\begin{array}{c}\text { Anggota } \\
\text { Agrowisata (Rp) }\end{array}$ & $\begin{array}{c}\text { Non-anggota } \\
\text { Agrowisata (Rp) }\end{array}$ & $\begin{array}{c}\text { Seluruh Responden } \\
\text { (Rp) }\end{array}$ \\
\hline Total Penerimaan Usahatani (a) & 35.141 .125 & 34.485 .255 & 34.670 .007 \\
\hline Total Penerimaan Agrowisata (b) & 2.695 .100 & 0 & 0 \\
\hline Total Biaya (c) & 13.695 .104 & 12.510 .739 & 12.845 .398 \\
\hline Total Pendapatan (a+b-c) & 24.141 .121 & 21.974 .516 & 21.824 .609 \\
\hline
\end{tabular}

Sumber: Analisis Data Primer, 2018

Tabel 5. Hasil Uji Koefisien Determinasi $\left(R^{2}\right)$ Analisis Faktor Sosial Ekonomi yang Mempengaruhi Pendapatan Petani Pada Usahatani Bunga Potong Krisan di Kecamatan Bandungan, Kabupaten Semarang

\begin{tabular}{|l|c|r|r|r|}
\hline \multicolumn{5}{|c|}{ Model Summary } \\
\hline \multicolumn{1}{|c|}{ Model } & $\mathbf{R}$ & R Square & Adjusted R Square & Std. Error of the Estimate \\
\hline 1 & $0,975^{\mathrm{a}}$ & 0,951 & 0,944 & $2,27501 \mathrm{E} 6$ \\
\hline
\end{tabular}

Sumber: Analisis Data Primer, 2018

Tabel 6. Hasil Uji F Analisis Faktor Sosial Ekonomi yang Diduga Berpengaruh Terhadap Pendapatan Petani Pada Usahatani Bunga Potong Krisan di Kecamatan Bandungan, Kabupaten Semarang

\begin{tabular}{|c|l|c|r|r|r|}
\hline Model & Sum of Squares & Df & Mean Square & F & \multicolumn{1}{c|}{ Sig. } \\
\hline 1 Regression & $6,168 \mathrm{E} 15$ & 8 & $7,711 \mathrm{E} 14$ & 148,976 & $0,000^{\mathrm{a}}$ \\
\hline Residual & $3,209 \mathrm{E} 14$ & 62 & $5,176 \mathrm{E} 12$ & & \\
\hline Total & $6,489 \mathrm{E} 15$ & 70 & & & \\
\hline
\end{tabular}

Sumber: Analisis Data Primer, 2018 
Agrisaintifika

Jurnal Ilmu-Ilmu Pertanian

Vol 3, No. 1, 2019

Kusumaningtyas, et al. 2019

Tabel 7. Hasil Uji F Analisis Faktor Sosial Ekonomi yang Diduga Berpengaruh Terhadap Pendapatan Petani Pada Usahatani Bunga Potong Krisan di Kecamatan Bandungan, Kabupaten Semarang

\begin{tabular}{|l|r|r|r|r|}
\hline \multicolumn{1}{|c|}{ Model } & \multicolumn{1}{c|}{$\begin{array}{c}\text { Unstandardized } \\
\text { Coefficients B }\end{array}$} & \multicolumn{1}{c|}{ Std. Error } & \multicolumn{1}{c|}{ T } & \multicolumn{1}{c|}{ Sig. } \\
\hline 1 (Constanst) & 1180711,810 & 6836104,473 & 0,173 & 0,863 \\
\hline Jumlah tenaga kerja luar & $-47322,503$ & 19620,237 & $-2,412^{*}$ & 0,019 \\
\hline Luas lahan yang diusahakan & $2,636 \mathrm{E} 8$ & 8755321,117 & $30,107^{*}$ & 0,000 \\
\hline Harga Jual & 112,016 & 399,386 & $0,280^{\text {ns }}$ & 0,780 \\
\hline Pendidikan petani & $-215886,102$ & 131505,430 & $-1,642^{\text {ns }}$ & 0,106 \\
\hline Pengalaman usahatani & 188233,037 & 70907,840 & $2,655^{*}$ & 0,010 \\
\hline Usia Petani & 1142,241 & 29235,776 & $0,039^{\text {ns }}$ & 0,969 \\
\hline JumlahTanggungan Keluarga & $-233923,499$ & 253773,157 & $-0,922^{\text {ns }}$ & 0,360 \\
\hline $\begin{array}{l}\text { Keikutsertaan petani dalam } \\
\text { pegelolaan agrowisata }\end{array}$ & 2003576,871 & 622468,898 & $3,219^{*}$ & 0,002 \\
\hline
\end{tabular}

Sumber: Analisis Data Primer, 2018 